\title{
Pengaruh Variasi Kosentrasi Ekstrak Daun Belimbing Wuluh (Averrhoa bilimbi L.) Terhadap Karakteristik Sediaan Salep Yang Menggunakan Basis PEG 4000 Dan PEG 400
} The Effect Of Various Concentrations Of Star Fruit (Averrhoa bilimbi L.) Leaves Extract On The Characteristics Of Ointment Using PEG 4000 AND PEG 400 Bases

\author{
Tri Puji Lestari ${ }^{1 *}$, Falenriana Ripo Sele ${ }^{2}$, Hariyani $^{3}$ \\ 1,2,3 Institut Ilmu Kesehatan Bhakti Wiyata Kediri \\ Jalan KH Wahid Hasyim 65 Kota Kediri \\ Email : tri.lestari@iik.ac.id*
}

\begin{tabular}{l||} 
Info artikel: \\
Diterima: \\
28/03/2021 \\
Direview: \\
18/04/21 \\
Diterbitkan: \\
09/05/2021 \\
\hline
\end{tabular}

\section{Info artikel:}

Diterima:

09/05/2021

\begin{abstract}
Abstrak
Daun belimbing wuluh (Averrhoa bilimbi L.) memiliki kandungan tanin dan flavonoid. Kandungan flavonoid dan tanin yang terdapat dalam belimbing wuluh mampu memberikan efek untuk menyembuhkan kulit yang mengalami kerusakan jaringan sel akibat luka bakar. Ada beberapa cara untuk pemanfaatan daun belimbing wuluh, antara lain dengan dibuat dalam sediaan salep. Penelitian ini bertujuan untuk mengetahui pengaruh berbagai konsentrasi ekstrak daun belimbing wuluh terhadap karakteristik sediaan salep yang menggunakan basis PEG 4000 dan PEG 400. Pada penelitian ini salep dibuat dengan variasi konsentrasi ekstrak daun belimbing wuluh sebesar 10\%, 15\%, dan 20\% yang menggunakan basis PEG 4000 dan PEG 400. Ekstrak daun belimbing wuluh diperoleh dengan menggunakan metode maserasi dengan menggunakan etanol $70 \%$ sebagai pelarutnya. Salep yang sudah dibuat kemudian dilakukan uji karakteristik, yang meliputi uji organoleptis, homogenitas, daya lekat dan uji daya sebar. Hasil uji organoleptis dan homogenitas dianalisis secara deskrisptif sedangkan hasil uji daya lekat dan uji daya sebar diolah dengan menggunakan metode statistik one-way ANOVA. Salep yang dihasilkan berbentuk semipadat dengan warna hijau muda sampai hijau kehitaman, serta tampak homogen. Nilai daya sebar dari ketiga formula menunjukkan perbedaan yang signifikan, sedangkan daya lekat dan nilai pH tidak berbeda signifikan antar tiga formula. Dengan demikian perbedaan konsentrasi zat aktif dalam salep berpengaruh terhadap daya sebar dari sediaan salep ekstrak daun belimbing wuluh yang menggunakan basis PEG 4000 dan PEG 400.
\end{abstract}

Kata kunci: Averrhoa bilimbi L.; salep; PEG.

\section{Abstract}

Wuluh starfruit (Averrhoa bilimbi L.) leaf contains tannins and flavonoids. The flavonoids and tannins in wuluh starfruit may exhibit effects, such as, skin damaged cell tissue healing from burns. There are several methods for the effective utilization of Averrhoa bilimbi L., among others, by preparing the wuluh starfruit leaf in ointment dosage form. This study aimed to investigate the effect of wuluh starfruit leaf extract ointment preparation using PEG 4000 and PEG 400 bases at various concentrations of 10\%, 15\%, and 20\%. Wuluh starfruit leaf extract was obtained by maceration method using $70 \%$ ethanol as solvent. The characteristics of resulting ointments were evaluated, including organoleptic, homogeneity, adhesion, and spreadability tests. The results of the organoleptic and homogeneity tests were analyzed descriptively, whereas the results of the adhesion and the spreadability tests were analyzed statistically using one-way ANOVA method. The resulting ointments of three formulae were semisolid, light green to blackish green, and homogeneous. The spreadability values of the three formulae differed significantly. In contrast, the results of the adhesion and $\mathrm{pH}$ values showed no significant difference among the three formulae. Thus the various concentrations of the active substance in ointment affected the spreadability of the wuluh starfruit leaf extract ointment using PEG 4000 and PEG 400 bases.

Keywords: Averrhoa bilimbi L.; ointment; PEG. 


\section{PENDAHULUAN}

Saat ini penggunaan bahan herbal untuk penggantian obat-obat kimia telah banyak dilakukan, salah satu tanaman yang dipercaya masyarakat dapat menyembuhkan luka yaitu tanaman belimbing wuluh (Averrhoa bilimbi L.). Senyawa yang terdapat pada ekstrak daun belimbing antara lain flavonoid, saponin, triterpenoid, dan tanin (Hayati, dkk., 2010). Secara kimia, flavonoid dan polifenol mempunyai aktivitas sebagai antiseptik (Harborne, 1987), sementara tanin dan senyawa turunannya bekerja dengan cara menciutkan selaput lendir pada saluran bagian kulit yang luka. Pada perawatan untuk luka bakar, tanin dapat mempercepat pembentukan jaringan yang baru sekaligus dapat melindunginya dari infeksi atau sebagai antiseptik (Sari dan Sari, 2011).

Penelitian ini menggunakan sediaan salep karena memiliki beberapa kelebihan seperti sebagai pelindung untuk mencegah kontak permukaan kulit dengan rangsang kulit, stabil dalam penggunaan dan penyimpanan, mudah dipakai, mudah terdistribusi merata dan sebagai efek proteksi terhadap iritasi, mekanik, panas, dan kimia (Ansel, dkk., 2005). Komponen yang terdapat pada salep selain bahan aktif adalah basis salep sebagai pembawa, di mana basis ini dibutuhkan untuk menghantarkan obat menuju tempat aksinya. Zat aktif harus bisa terlepas terlebih dahulu dari basis salepnya supaya zat tersebut dapat berkhasiat sesuai dengan efek farmakologinya (Idzon dan Lazarus, 1986). Polietilenglikol (PEG) adalah salah satu bahan yang bisa digunakan sebagai basis salep di mana PEG ini memiliki distribusi dan daya lekat yang baik, tidak mengiritasi, dan memiliki efektifitas yang lebih lama karena PEG tidak menghambat produksi keringat dan pertukaran gas (Voigt, 1984). Untuk meningkatkan efektivitas penggunaan ekstrak daun belimbing wuluh pada kulit, maka dibuat formulasi ekstrak daun belimbing wuluh dengan menggunakan kombinasi basis PEG 4000 dan PEG 400. Kombinasi ini memberikan keuntungan dimana salep yang dihasilkan menjadi lebih lunak atau meleleh ketika diaplikasikan pada kulit karena PEG 400 bobot molekulnya rendah dan PEG 4000 bobot molekulnya inggi (Idzon dan Lazarus, 1986).

\section{Alat dan Bahan \\ II.METODE PENELITIAN}

Alat-alat yang digunakan dalam penelitian ini adalah beaker gelas, erlenmeyer, cawan porselin, gelas ukur, batang pengaduk, tabung reaksi, rak tabung reaksi, timbangan analitik, ayakan, mortir dan stemper, penangas air, kaca bulat, kaca objek, dan $\mathrm{pH}$ meter. Bahan- bahan yang digunakan dalam penelitian ini adalah serbuk daun belimbing wuluh, etanol 70\%, amil alkohol, serbuk magnesium (Mg), $\mathrm{HCl}$ pekat, $\mathrm{FeCl}_{3}$, eter, alfa-tokoferol, metil paraben, propil paraben, PEG 400, dan PEG 4000.

\section{Penyiapan Sampel}

Daun belimbing wuluh (Averrhoa bilimbi L.) yang telah dikumpulkan dicuci, selanjutnya daun belimbing wuluh dikeringkan dengan cara diangin-anginkan sampai kering dan terlindung dari sinar matahari langsung. Simplisia yang telah kering ditimbang dan diblender sampai halus, lalu diayak. Serbuk halus ditimbang sebanyak 500 g untuk selanjutnya diekstraksi dengan menggunakan pelarut etanol 70\% (Triswanto, 2015).

\section{Pembuatan Ekstrak Daun Belimbing} Wuluh

Sebanyak 500g serbuk daun beliming wuluh (Averrhoa bilimbi L) diekstraksi menggunakan metode maserasi (maserasi menggunakan perbandingan 1:10 
yaitu 500 gram serbuk daun belimbing wuluh direndam dengan $5 \mathrm{~L}$ etanol $70 \%$. Ditutup dan dibiarkan selama 3 hari terlindung dari cahaya matahari sambil diaduk berulang. Setelah 3 hari disaring menggunakan kertas saring, filtrat yang diperoleh di remaserasi selama 2 hari dengan pelarut secukupnya. Setelah semua ekstrak cair didapat kemudian diuapkan di waterbath dan diperoleh ekstrak kental (Triswanto, 2015).

\section{Skrining Fitokimia Ekstrak Daun Belimbing Wuluh}

Uji kandungan senyawa pada daun belimbing wuluh (Averrhoa bilimbi L.) dilakukan dengan uji pereaksi warna untuk mengidentifikasi senyawa flavonoid dan tanin, sebagai berikut:

a. Uji flavonoid

Sebanyak 10 tetes ekstrak daun belimbing wuluh dimasukkan ke dalam tabung reaksi, ditambah 2 tetes $\mathrm{HCl}$ pekat, dan serbuk Mg. Terbentuknya warna merah memberikan indikasi keberadaan flavonoid dalam sampel (Marliana ,dkk., 2005).

b. Uji tanin

Sebanyak 10 tetes ekstrak daun belimbing wuluh ditambah dengan $10 \mathrm{ml}$ air suling, kemudian disaring. Filtrat diencerkan dengan air suling sampai tidak berwarna. Kepada $2 \mathrm{ml}$ filtrat tersebut ditambahkan sebanyak 1 sampai 2 tetes pereaksi $\mathrm{FeCl}_{3}$. Terbentuknya warna kehitaman memberikan indikasi keberadaan tanin dalam sampel (Sa'adah, 2010).

\section{Formula dan Pembuatan Salep Ekstrak}

\section{Daun Belimbing Wuluh}

a. Formula salep

Formula sediaan salep dapat dilihat pada Tabel 1.

Tabel 1. Formula salep ekstrak daun belimbing wuluh (Averrhoa bilimbi $\mathrm{L}$.

\begin{tabular}{llccl}
\hline \multicolumn{1}{c}{ Bahan $(g)$} & Fungsi & FI & FII & FIII \\
& & & & \\
\hline Ekstrak kental & Zat Aktif & $10 \%$ & $15 \%$ & $20 \%$ \\
Alfa-tokoferol & Antioksida & $0,01 \%$ & $0,01 \%$ & $0,01 \%$ \\
Metil paraben & Pengawet & $0,02 \%$ & $0,02 \%$ & $0,02 \%$ \\
Propil paraben & Pengawet & $0,01 \%$ & $0,01 \%$ & $0,01 \%$ \\
PEG 4000 & Basis salep & $17,6 \%$ & $17,6 \%$ & $17,6 \%$ \\
PEG 400 & Basis salep & $73,9 \%$ & 73,9 & $73,9 \%$ \\
\hline Total & & 100 & 100 & $100 \%$ \\
\hline
\end{tabular}

b. Pembuatan sediaan salep

Ditimbang PEG 4000, dimasukkan ke dalam cawan porselen, dan kemudian dilebur di atas penangas air. Basis yang telah meleleh diaduk hingga homogen dalam mortar. PEG 400 ditambahkan, dan diaduk hingga terbentuk massa yang kental dan homogen, dan selanjutnya ditambahkan metil paraben, propil paraben, alfa-tokoferol, dan diaduk hingga homogen. Ekstrak ditambah sedikit demi sedikit ke dalam campuran tersebut, lalu diaduk hingga homogen.

\section{HASIL DAN PEMBAHASAN}

Dilakukan maserasi terhadap serbuk simplisia yang dihasilkan dengan menggunakan pelarut etanol 70\%. Dipilih etanol $70 \%$ karena pelarut ini mampu menyari senyawa flavonoid yang terkandung di dalam serbuk simplisia. Keuntungan cara maserasi ialah, cara pengerjaan dan peralatan yang digunakannya sederhana dan mudah dilakukan. Proses maserasi dilakukan selama 2 hari dan dilanjutkan dengan re-maserasi selama 2 hari kemudian. Hasil maserat yang diperoleh kemudian diuapkan, dengan tujuan untuk menguapkan etanol hingga dihasilkan ekstrak kental sebanyak 73,34 gram. Dengan demikian rendemen yang dihasilkan sebesar 14,6\%. 


\section{Uji karakteristik sediaan salep}

\section{Uji organoleptis}

Berdasarkan pada pengamatan hasil organoleptis, ditemukan bahwa variasi konsentrasi ekstrak daun belimbing wuluh dalam salep berpengaruh pada warna salep, namun tidak berpengaruh pada konsistensi dan bau sediaan salep. Sediaan salep daun belimbing wuluh berbau khas ekstrak daun belimbing wuluh. Warna sediaan salep yang mengandung konsentrasi ekstrak belimbing wuluh $20 \%$ cenderung lebih hijau kehitaman dari pada salep yang mengandung konsentrasi $10 \%$ dan $15 \%$ ekstrak. Konsistensi seluruh formula sediaan salep adalah setengah padat.

\section{Uji homogenitas}

Seluruh formula salep menunjukkan hasil yang homogen. Hal ini ditandai dengan sebaran ekstrak daun belimbing wuluh yang merata dan tidak teramati adanya butiran kasar yang bergerombol pada objek gelas.

\section{Uji daya sebar}

Tabel 2. Hasil uji daya sebar sediaan salep ekstrak daun belimbing wuluh

\begin{tabular}{llcl}
\hline Sediaan & Replikasi & $\begin{array}{c}\text { Daya sebar } \\
(\mathrm{cm})\end{array}$ & Rata-rata \pm SD \\
\hline Formula I & 1 & 5,45 & $5,48 \pm 0,02$ \\
& 2 & 5,5 & \\
& 3 & 5,5 & \\
\hline Fomula II & 1 & 5,15 & $5,25 \pm 0,13$ \\
& 2 & 5,4 & \\
\hline Formula III & 1 & 5,2 & \\
& 2 & 5,1 & $5,01 \pm 0,07$ \\
& 3 & 5 & \\
\hline
\end{tabular}

Hasil uji daya sebar dari seluruh formula memenuhi persyaratan uji daya sebar 5-7 cm (Tabel 2). Hasil rata-rata uji daya sebar formula I $5,48 \mathrm{~cm}$, formula II $5,25 \mathrm{~cm}$, dan formula III 5,01 cm. Hasil uji daya sebar formula III menunjukkan nilai yang terendah. Normalitas data yang diperoleh pada seluruh formula diuji untuk mengetahui apakah data terdistribusi secara normal. Hasil uji normalitas menunjukkan bahwa data terdistribusi secara normal, yang ditunjukkan dengan nilai signifikansi 0,220>0,05. Selanjutnya dilakukan pengujian homogenitas data, dan diperoleh hasil 0,093>0,05 yang berarti bahwa data memiliki variasi yang homogen. Hasil pengujian one way ANOVA menunjukkan nilai signifikansi $0,002<0,05$, yang berarti ada perbedaan yang nyata pada daya sebar antar tiga formula. Oleh sebab itu uji dilanjutkan dengan LSD (Least Significant Difference) untuk melihat formula mana yang menunjukkan perbedaan dengan formula lainnya.

Daya sebar sediaan salep formula I berbeda bermakna dengan daya sebar formula II dan III. Nilai signifikansi berturut-turut adalah $0,019<0,05$ dan $0,001<0,05$. Daya sebar formula II berbeda bermakna dengan formula I dan III, dengan nilai signifikansi berturut-turut adalah $0,019<0,05$. Daya sebar formula III berbeda bermakna dengan formula I dan II, dengan nilai signifikansi berturut-turut adalah $0,001<0,05$ dan $0,019<0,05$. Dengan demikian daya sebar dari tiga formula sediaan salep berbeda secara nyata. Dengan kata lain, perbedaan konsentrasi zat aktif yang digunakan dalam sediaan salep berpengaruh nyata terhadap daya sebarnya. Sediaan salep yang nyaman digunakan, memiliki daya sebar antara 5-7 cm (Garg, dkk., 2002). Dengan demikian seluruh formula sediaan salep yang dibuat memenuhi daya sebar sediaan salep yang baik atau nyaman digunakan pada kulit. Semakin besar konsentrasi ekstrak yang digunakan, daya sebarnya semakin menurun. Hal ini disebabkan penambahan konsentrasi ekstrak yang tinggi (formula III) membuat salep semakin pekat sehingga meningkatkan konsistensi sediaan salep yang pada gilirannya menyebabkan penurunan daya sebar sediaan salep. 


\section{Uji pH}

Tabel 3. Nilai pH sediaan salep ekstrak daun belimbing wuluh

\begin{tabular}{|c|c|c|c|}
\hline Sediaan & Replikasi & $\mathrm{pH}$ & $\begin{array}{l}\text { Rata-rata } \pm \\
\text { SD }\end{array}$ \\
\hline \multirow{3}{*}{ Formula 1} & 1 & 5,4 & \multirow{3}{*}{$5,46 \pm 0,05$} \\
\hline & 2 & 5,5 & \\
\hline & 3 & 5,5 & \\
\hline \multirow[t]{3}{*}{ Formula 2} & 1 & 5,5 & \multirow[t]{3}{*}{$5,53 \pm 0,05$} \\
\hline & 2 & 5,5 & \\
\hline & & 5,6 & \\
\hline \multirow[t]{3}{*}{ Formula 3} & 1 & 6,0 & \multirow[t]{3}{*}{$5,63 \pm 0,32$} \\
\hline & 2 & 5,5 & \\
\hline & 3 & 5,4 & \\
\hline
\end{tabular}

Uji $\mathrm{pH}$ bertujuan untuk mengetahui keamanan sediaan salep pada saat dioleskan di permukaan kulit, yaitu tidak mengiritasi kulit. Nilai pH kulit sekitar 4,5 sampai 6,5. Sediaan salep ekstrak daun belimbing wuluh menunjukkan nilai $\mathrm{pH}$ rata-rata sebesar $5,46 \pm 0,05 ; 5,53 \pm 0,05$; dan 5,63 $\pm 0,32$ (Tabel 3). Dengan demikian nilai $\mathrm{pH}$ sediaan salep ekstrak daun belimbing wuluh berada di dalam rentang nilai $\mathrm{pH}$ kulit. yaitu berada pada rentang 4,5 sampai 6,5. Normalitas data yang diperoleh pada seluruh formula sediaan salep diuji dengan Shapiro-Wilk test. Hasil uji menunjukkan bahwa data terdistribusi secara normal, yang ditunjukkan dengan nilai signifikansi 0,243>0,05. Selanjutnya dilakukan uji homogenitas data dan diperoleh hasil bahwa data memiliki varian yang sama (homogen), dengan nilai signifikansi 0,318>0,05. Pengolahan data dilanjutkan dengan uji statistik one way ANOVA untuk melihat apakah terdapat perbedaan yang bermakna pada nilai $\mathrm{pH}$ antar tiga formula sediaan salep. Diperoleh nilai signifikansi 0,749>0,05 yang berarti bahwa $\mathrm{pH}$ antar formula I, II, dan III dari sediaan salep tidak berbeda secara nyata.

\section{Uji daya lekat}

Tabel 4. Hasil uji daya lekat sediaan salep ekstrak daun belimbing wuluh

\begin{tabular}{llll}
\hline Sediaan & Replikasi & Daya Lekat & $\begin{array}{l}\text { Rata-rata } \\
\text { SD }\end{array}$ \\
\hline Formula 1 & \multicolumn{1}{l}{1} & 55 & $57 \pm 2$ \\
& 2 & 57 & \\
\cline { 2 - 3 } & 3 & 59 & $56 \pm 5,5$ \\
\hline Formula 2 & 1 & 53 & \\
\cline { 2 - 3 } & 2 & 61 & \\
\hline
\end{tabular}

\begin{tabular}{|c|c|c|c|}
\hline & 3 & 55 & \\
\hline \multirow{3}{*}{ Formula 3} & 1 & 53 & \multirow{3}{*}{$56 \pm 4,1$} \\
\hline & 2 & 54 & \\
\hline & 3 & 63 & \\
\hline
\end{tabular}

Hasil rata-rata daya lekat sediaan salep formula I, II, dan III masing-masing adalah 57 detik, 56 detik, dan 56 detik (Tabel 4). Uji daya lekat berfungsi untuk mengetahui lama pelekatan salep pada permukaan kulit. Semakin lama suatu sediaan salep melekat pada kulit, senakin besar absorbsi zat aktif melalui permukaan kulit. Daya lekat sediaan salep yang baik menunjukkan daya lekat lebih dari 4 detik. Hasil uji daya lekat menunjukkan bahwa semua formula sediaan salep ekstrak daun belimbing wuluh memenuhi syarat, dengan lama pelekatan salep tidak kurang dari 4 detik. Uji normalitas data yang dilakukan dengan Shapiro-Wilk test menunjukkan bahwa data yang diperoleh pada seluruh formula sediaan salep, terdistribusi secara normal, dengan nilai signifikansi $0,239>0,05$. A n a 1 is is data dilanjutkan dengan uji homogenitas yang menunjukkan nilai signifikansi $0,165>0,05$. Dengan demikian data memiliki varian yang sama (homogen). Hasil uji analisis statistik one way ANOVA menunjukkan tidak adanya perbedaan yang nyata pada daya lekat antar tiga formula sediaan salep ekstrak daun belimbing wuluh, dengan nilai signifikansi 0,981>0,05. Dengan demikian perbedaan konsentrasi ekstrak daun belimbing wuluh pada sediaan salep tidak berpengaruh pada daya lekatnya di permukaan kulit.

\section{PENUTUP}

Dari hasil penelitian ini dapat disimpulkan bahwa seluruh formula sediaan gel antiseptik tangan (F1, F2, F3) memiliki mutu fisik sediaan yang baik. Formula sediaan gel F2 dan F3 yang mengandung minyak atsiri daun kemangi pada konsentrasi $6 \%$ dan $8 \%$ 
(b/b) memiliki daya hambat Staphylococcus aureus dalam kategori kuat, sedangkan formula sediaan gel F1 yang mengandung $4 \%$ (b/b) zat aktif memiliki aktivitas antibakteri dalam kategori sedang. perbedaan konsentrasi salep ekstrak daun belimbing wuluh pada sediaan salep berpengaruh terhadap daya sebarnya, namun tidak berpengaruh pada karakteristik organoleptis, homogenitas, daya lekat, dan $\mathrm{pH}$ sediaan salep

\section{UCAPAN TERIMAKASIH}

Penulis mengucapkan terimakasih pada Institut Bhakti Wiyata Kediri serta semua pihak yang telah memberikan banyak dukungan sehingga penelitian ini dapat terselesaikan dengan baik dan lancar.

\section{DAFTAR PUSTAKA}

Anief, M.1997. Ilmu Meracik Obat. Gajah Mada University Press : Yogyakarta.

Ansel, H. C., Allen, L. V., Popovich, N. G.,2005. Ansel's Pharmaceutical Dosage Forms and Drug Delivery Systems. Eighth Edition. Lippincott: USA.

Astuti I. Y., D. Hartanti, dan A. Aminiati.2010. Peningkatan Aktivitas Antijamur Candida albicans Salep Minyak Atsiri Daun Sirih (Piperbettle LINN.) melalui Pembentukan Kompleks Inklusi dengan $\beta$-siklodekstrin. Majalah Obat Tradisional. Vol 15 No 3. Hlm 94-99.

Garg, A., Agrawal, D., Garg, S., Singla, A. K.,. 2002. Spreading of Semisolid Formulations: An Update. Pharmaceutical Technology. Vol 26. No.29. hlm 84-105.

Harborne, J. B., 1987. Metode Fitokimia. Edisi Kedua. ITB :Bandung.
Hayati, E. K., Jannah, A., Mukhlisoh, W., 2010. Pengaruh Ekstrak Tunggal dan Gabungan Daun Belimbing Wuluh (Averrhoa bilimbi L.) terhadap Efektivitas Antibakteri secara in Vitro. Kimia. UIN Malang: Malang.

Idzon, B. dan Lazarus, J., 1986. Semi Solid, dalam Lachman, L. Lieberman, H. A., Kanig, J. L. The Theory and Practice of Industrial Pharmacy. Lea and Febiger: Philadelphia.

Marliana, S. D., Suryanti, V., Suyono, 2005. Skrining Fitokimia dan Analisis Kromatografi Lapis Tipis Komponen Kimia Buah Labu Siam (Sechium edule Jacq. Scwartz.) dalam Ekstrak Etanol. Biofarmasi. UNS: Surakarta.

Naibaho, O. H., Yamlean, P. V. Y., Wiyono, W., 2013. Pengaruh Basis Salep terhadap Formulasi Sediaan Salep Ekstrak Daun Kemangi (Ocimum sanctum, L.) pada Kulit Punggung Kelinci yang Dibuat Infeksi Staphylococcus aureus. Jurnal Ilmiah Farmasi, Vol. 2 No. 02. Hlm 27-3

Sa'adah, L., 2010. Isolasi dan Identifikasi Senyawa Tanin dari Daun Belimbing Wuluh (Averrhoa bilimbi L.). Skripsi. Fakultas Sains dan Teknologi Universitas Islam Negeri Maulana Malik Ibrahim: Malang.

Sari, F. P. dan Sari, S. M., 2011. Ekstraksi Zat Aktif Antimikroba dari Tanaman Yodium (Jatropha multifida Linn) sebagai Bahan Baku Alternatif Antibiotik Alami. Fakultas Teknik Universitas Diponegoro: Semarang. 
Lestari- Pengaruh Variasi Konsentrasi Ekstrak Daun Belimbing Wuluh (Averrhoa bilimbi L.) Terhadap Karakteristik Sediaan Salep Yang Menggunakan Basis PEG 4000 dan PEG 400- Vol.02 No 02 Hal 7-13

Triswanto, 2015. Uji Aktivitas Ekstrak Etanol Daun Alpukat (Persea americana Mill.) Terhadap Penyembuhan Luka Luka Bakar Pada Punggung Mencit Jantan (Mus musculus). Jurnal Ilmiah Manuntung. Vol 1 No 2. Hlm 100106.

Voigt, 1984. Buku AjarTeknologi Farmasi.

Diterjemahkan oleh Soendani

Noeroto S. UGM Press:

Yogyakarta. 